\title{
A MYNACH BY ANY OTHER NAME . . . : THE ANTHROPONYMY OF THE WELSH CISTERCIANS, c.1300-1540
}

\author{
DAVID E. THORNTON \\ Bilkent University, Ankara, Turkey
}

\begin{abstract}
This paper analyses the forenames and 'surnames' of over 600 monks associated with Cistercian abbeys in Wales between c.1300 and c.1540 in an attempt to determine what these names can reveal about the ethnic identities or identifications of their individual bearers and of their respective houses. The names are compared with those of white monks and other religious in England during the same period, as well as with naming patterns among the laity of contemporary Wales and England. The names of the brethren at different monasteries could vary significantly, and it is argued that this was a result partly of the stronger Welsh identity of the monks at certain Cistercian houses, but was also because the practice of adopting 'monastic bynames' - common at monasteries in late medieval England - was followed at some Welsh abbeys but not all.
\end{abstract}

The importance and popularity of the Cistercian Order in medieval Wales is a fact long recognized by historians. ${ }^{1}$ Indeed, of the forty monasteries in Wales that survived until the period of the Dissolution in the late 1530s, fifteen ( 37.5 per cent) were Cistercian: 13 houses of monks and two nunneries. ${ }^{2}$ No other monastic order could boast as many Welsh houses at that time. This stands in contrast to England,

${ }^{1}$ For the Cistercians in Wales in general, see David H. Williams, The Welsh Cistercians (Leominster, 2001); David M. Robinson, The Cistercians in Wales: Architecture and Archaeology 1130-1540 (London, 2006).

${ }^{2}$ These figures are based on information from David Knowles and R. Neville 
where Cistercian houses probably accounted for less than 15 per cent of the monasteries by c.1534-40. Furthermore, Cistercian abbeys were located throughout Wales whereas, for example, the Benedictines were conspicuous by their absence in north Wales, and the Augustinian canons, with eight priories and one abbey, were absent in mid-Wales and the north-east. ${ }^{3}$ The Cistercians therefore constituted a significant proportion of the 'regular' population of Wales before the Dissolution. In addition, however, historians have traditionally regarded the Cistercian order as being somehow special for the medieval Welsh and their rulers. Thus, J. E. Lloyd, for example, wrote that 'the Welsh element had found its true place in the Cistercian world', ${ }^{4}$ and later Rees Davies described how the Cistercians 'in particular established deep roots in Wales' and 'caught the imagination of the Welsh'. ${ }^{5}$ Who therefore were the religious inmates of these Cistercian houses that were seemingly so important for Wales and the Welsh prior to the Dissolution, and to what extent did they have a 'Welsh identity', especially after 1282-3? This paper will use the names (forenames and so-called 'surnames') of the white monks in Wales from $c .1300$ onwards to examine this question.

The expansion of the Cistercian Order in Wales covered a hundred-year period from $c .1130$, initially under the patronage of Anglo-Norman lords (1130-47) but from the 1160s onwards with the enthusiastic support of native Welsh rulers. ${ }^{6}$ The last house of Welsh Cistercians was established at Grace Dieu Abbey in Monmouthshire, in 1226. In addition to the thirteen male Cistercian houses in Wales, there were two Welsh nunneries associated with the Order, at Llanllŷr, Ceredigion, and Llanllugan in Cedewain, both founded in the late twelfth century or, in the case of Llanllugan, perhaps a little later, and both under Welsh patronage. ${ }^{7}$

Hadcock, Medieval Religious Houses: England and Wales (2nd edn, London, 1971), and the Monastic Wales website: www.monasticwales.org/

3 These distributions are best represented visually via the maps on the Monastic Wales website, and also by those in Janet Burton and Karen Stöber, Abbeys and Priories of Medieval Wales (Cardiff, 2015), pp. 8, 11, 14.

${ }^{4}$ John Edward Lloyd, A History of Wales from the Earliest Times to the Edwardian Conquest, 2 vols (3rd edn, London, 1939), II, p. 597.

5 R. R. Davies, The Age of Conquest: Wales 1063-1415 (Oxford, 1987), pp. 196-7.

${ }^{6}$ Williams, Welsh Cistercians, pp. 3-8; Robinson, Cistercians in Wales, pp. 24-31.

7 For these two female houses, see David H. Williams, 'Cistercian nunneries in medieval Wales', Citeaux: Commentarii Cistercienses, 26 (1975), 155-74; David H. Williams, 'The Cistercians in Wales: 2. Ceredigion', Archaeologia Cambrensis, 159 (2010), 241-86 (266-9); Burton and Stöber, Abbeys and Priories, pp. 120-4; Jane 
Finally, Abbey Dore, located just over the border in Herefordshire, has often been treated together with the Welsh Cistercian abbeys proper and by 1521 at least it was considered part of a provincia Wallie. ${ }^{8}$ As with most religious houses in Wales, the majority of these sixteen Cistercian houses (if we include Dore) were closed by Henry VIII's government in 1536-7, as part of the suppression of the lesser monasteries, and only the abbeys at Neath, Strata Florida and Whitland survived until the final 'voluntary surrenders' in $1539 .{ }^{9}$ What do we know about the ethnic, cultural and even political sympathies of these religious communities during the four centuries of Cistercian monasticism in Wales, and in particular can we argue that the white monks in late medieval Wales - or some of them at least - had a distinctly and consciously Welsh identity? Although only half of the Cistercian monasteries in Wales had been founded by Welsh rulers, at least a number of the Anglo-Norman foundations, such as Strata Florida and Whitland, were located in what became known as Pura Wallia - the fluctuating territories controlled directly by native Welsh rulers - and patronage of some did subsequently pass into Welsh hands. ${ }^{10}$ Furthermore, native rulers granted charters to most Cistercian houses, even those outside their direct political influence, as evidenced by the extant documents catalogued and printed by Huw Pryce in his Acts of Welsh Rulers. ${ }^{11}$ In addition, both before and after the Edwardian conquest, the Cistercian abbeys in particular were closely associated with the promotion of medieval Welsh culture, both through the composition

Cartwright, Feminine Sanctity and Spirituality in Medieval Wales (Cardiff, 2008), pp. 176-208; M. Gray and J. Morgan-Guy, “"A better and frugal life”: Llanllugan and the Cistercian Women's Houses in Wales', Archaeologia Cambrensis, 154 (2005), $97-11$.

8 C. H. Talbot (ed.), Letters from the English Abbots to the Chapter at Citeaux, 14421521, Camden Society, 4th series, 4 (London, 1967), pp. 161-2; Williams, Welsh Cistercians, p. 160.

${ }^{9}$ Burton and Stöber, Abbeys and Priories, p. 30; Williams, Welsh Cistercians, pp. 85-6; Robinson, Cistercians in Wales, p. 36.

${ }^{10}$ On the 'political' associations of Welsh Cistercian abbeys in the twelfth and thirteenth centuries, see David Stephenson, 'The rulers of Gwynedd and Powys', in Janet Burton and Karen Stöber (eds), Monastic Wales: New Approaches (Cardiff, 2013), pp. 89-102; Owain Wyn Jones, 'Historical writing in medieval Wales' (unpublished $\mathrm{PhD}$ thesis, Bangor University, 2013), pp. 317-31; Williams, Welsh Cistercians, pp. 26-32.

${ }^{11}$ Huw Pryce (ed.), The Acts of Welsh Rulers 1120-1283 (Cardiff, 2005), p. 55; see also idem, 'Patrons and patronage among the Cistercians in Wales', Archaeologia Cambrensis, 154 (2007), 81-95. 
and/or transmission of literary, historical, genealogical and legal texts in Latin and Welsh ${ }^{12}$ and also, during the fifteenth century especially, the patronage of Welsh uchelwyr poets. ${ }^{13}$ Table 1 attempts to summarize, somewhat crudely, the Welsh associations of the sixteen houses of white monks and nuns, including Abbey Dore.

Only at three monasteries do there appear to have been no 'Welsh' political, economic and/or cultural associations during the Middle Ages: Dore, Grace Dieu, and Tintern. Interestingly, these same three houses are also to be distinguished from the other Cistercian monasteries in terms of their filiation: Abbey Dore and its daughter-house Grace Dieu were the only abbeys in Wales of the filiation of Morimond, and similarly Tintern was uniquely of the L'Aumône filiation. ${ }^{14}$ (The majority of Welsh houses of white monks belonged to the filiation of Clairvaux and were daughters of Whitland or, in a few cases, had been Savigniac monasteries incorporated into the Cistercian Order in 1147.) Furthermore, the wider filiations of Dore, Grace Dieu and Tintern looked to England, whereas the other Welsh houses were very much focused on Wales: thus,

12 Daniel Huws, Medieval Welsh Manuscripts (Cardiff, 2000), esp. pp. 52-3, 75-6, 189-92, 215-18, 252-4; Ceridwen Lloyd-Morgan, 'Manuscripts and the monasteries', in Burton and Stöber (eds), Monastic Wales, pp. 209-27; David N. Bell, 'Medieval Welsh Cistercian libraries: a reappraisal', Citeaux, 64 (2013), 115-54; Jones, 'Historical writing in medieval Wales'; Ben Guy, 'A lost medieval manuscript from north Wales: Hengwrt 33, the Hanesyn Hên', Studia Celtica, 50 (2016), 69-105; Huw Pryce, 'Chronicling and its contexts in medieval Wales', in Ben Guy, Owain Wyn Jones, Georgia Henley and Rebecca Thomas (eds), The Chronicles of Medieval Wales and the March: New Contexts, Studies and Texts (Turnhout, 2020), pp. 1-32; Barry J. Lewis, 'Bonedd y Saint, Brenhinedd y Saesson, and historical scholarship at Valle Crucis Abbey', in Guy et al. (eds), The Chronicles of Medieval Wales, pp. 140-54.

${ }^{13}$ Dafydd Johnston, 'Monastic patronage of Welsh poetry', in Burton and Stöber (eds), Monastic Wales, pp. 177-90 (p. 179); see also Karen Stöber, 'The Cistercians and the bards - praise and patronage in fifteenth-century Wales', in Dylan Foster Evans, Barry J. Lewis and Ann Parry Owen (eds), 'Gwalch Cywyddau Gwŷy': Ysgrifau ar Guto'r Glyn a Chymru'r Bymthegfed Ganrif. Essays on Guto'r Glyn and FifteenthCentury Wales (Aberystwyth, 2013), pp. 305-26; Catrin T. Beynon Davies, 'Y cerddi i'r tai crefydd fel ffynhonnell hanesyddol', National Library of Wales Fournal, 18 (1973-4), 269-86, 345-73; Helen Fulton, 'Literary networks and patrons in late medieval Wales,' in Geraint Evans and Helen Fulton (eds), The Cambridge History of Welsh Literature (Cambridge, 2019), pp. 129-53.

${ }^{14}$ For the filiations of Welsh houses, see Williams, Welsh Cistercians, p. 5; Robinson, Cistercians in Wales, p. 27; and, Janet Burton, 'Homines sanctitatis eximiae, religionis consummatae: the Cistercians in England and Wales,' Archaeologia Cambrensis, 154 (2007), 27-49. Prof. Burton's maps are particularly informative. 
Table 1. The Political and Cultural Associations of Welsh Cistercian Monasteries, c.1130-1540

\begin{tabular}{|l|c|c|c|}
\hline House & Welsh foundations & $\begin{array}{c}\text { Welsh princely } \\
\text { benefactions }\end{array}$ & $\begin{array}{c}\text { Welsh cultural } \\
\text { associations }\end{array}$ \\
\hline Aberconwy & $\checkmark$ & $\checkmark$ & $\checkmark$ \\
\hline Basingwerk & $\checkmark$ & $\checkmark$ & $\checkmark$ \\
\hline Cwmhir & $\checkmark$ & $\checkmark$ & $\checkmark$ \\
\hline Cymer & & & \\
\hline Dore & $\checkmark$ & $\checkmark$ & \\
\hline Grace Dieu & $\checkmark$ & & $\checkmark$ \\
\hline Llanllugan & $\checkmark$ & $\checkmark$ & $\checkmark$ \\
\hline Llanllyr & & $\checkmark$ & $\checkmark$ \\
\hline Llantarnam & & $\checkmark$ & $\checkmark$ \\
\hline Margam & & $\checkmark$ & $\checkmark$ \\
\hline Neath & $\checkmark$ & $\checkmark$ & $\checkmark$ \\
\hline Strata Florida & & $\checkmark$ & $\checkmark$ \\
\hline Strata Marcella & $\checkmark$ & & \\
\hline Tintern & & & \\
\hline Valle Crucis & & & \\
\hline Whitland & & & \\
\hline
\end{tabular}

for example, Abbey Dore established a daughter house at Vale Royal, Cheshire, and Tintern had a daughter at Kingswood in Gloucestershire.

Of course, medieval monasteries were not simply impersonal religious corporations, under the direction of a superior, but comprised communities of brothers or sisters who would have made their own personal contributions to the character and identity of their convents. The vast majority of medieval religious clergy, in both Wales and elsewhere, occur in the surviving written record merely as personal names and only occasionally, when they had done something notable - such as behaved inappropriately, been promoted, or autographed a manuscript - can we say a little more about the person behind the name. However, even names may reveal much information about the origins and 'identity' of their bearers and, in the case of the Welsh Cistercians for example, scholars have indeed offered some comments about the 
ethnicity of individual monasteries by examining the names of their inmates. ${ }^{15}$ Who therefore were the white monks in late medieval and early sixteenth-century Wales, and what can their forenames and surnames tell us about their respective religious communities?

\section{THE PROSOPOGRAPHY OF THE WELSH CISTERCIANS}

Our current knowledge of the prosopography of Welsh Cistercian monasteries is based in no small way on the tireless labours over the past four decades of David H. Williams. ${ }^{16}$ Drawing upon a variety of printed and unpublished sources, Revd Williams has compiled a list of the white monks of Wales, from the foundation of their houses in the twelfth and early thirteenth centuries down until the period of the Dissolution in the sixteenth century. In addition, the work of David Smith and others on the superiors of English and Welsh religious houses has furnished additional and sometimes alternative information about the Welsh Cistercian abbots. ${ }^{17}$ It should be mentioned here that the amount of prosopographical data concerning Cistercian nuns in medieval Wales is extremely limited, ${ }^{18}$ and consequently the following discussion will focus on male religious only. Using Williams's and Smith's publications, plus a few additional sources, I have identified the names of 648 white monks and abbots associated with the thirteen male Cistercian houses in Wales,

${ }^{15}$ Williams, Welsh Cistercians, pp. 127-9; note also Burton and Stober, Abbeys and Priories, p. 20.

${ }^{16}$ David H. Williams, 'Fasti Cistercienses Cambrenses', Archaeologia Cambrensis, 163 (2014), 185-235, which replaces the earlier 'Fasti Cistercienses Cambrenses', Bulletin of the Board of Celtic Studies, 24 (1970-2), 181-229, and 25 (1973), 156-7; see also Welsh entries in his The Tudor Cistercians (Leominster, 2014), pp. 414-565. Many of Williams's articles offer detailed studies of the personnel of individual houses.

${ }_{17}$ David M. Smith and Vera C. M. London, The Heads of Religious Houses: England and Wales, II: 1216-1377 (Cambridge, 2001); and, David M. Smith, The Heads of Religious Houses: England and Wales, III: 1377-1540 (Cambridge, 2008).

${ }^{18}$ David Williams has been able to determine the names of a grand total of just eight Welsh white nuns: 'Fasti' (2014), 230; Tudor Cistercians, pp. 547-65. On the problem of female monastic prosopography in general, see Kimm Curran, 'Looking for medieval female religious in Britain and Ireland: sources, methodologies and pitfalls', in Emilia Jamroziak, Judith Kerr and Karen Stöber (eds), Monastic Life in the British Isles: Essays in Honour of fanet Burton (Cardiff, 2018), pp. 161-212. 
plus Abbey Dore, between circa 1300 and 1540. Table 2 summarizes the numbers of monks according to individual monastery. ${ }^{19}$

One obvious conclusion from Table 2 is that the numbers recorded for individual abbeys vary significantly: at one extreme, we know the names of 115 and 99 monks at Dore and Tintern respectively; on the other hand, for Cymer Abbey we have only 15 names, at Valle Crucis 20, and Basingwerk and Grace Dieu fare little better with just 25 apiece.

David Williams has estimated that between 1130 and 1540 there must have been over 2,000 white monks in Wales, ${ }^{20}$ so the current number of 648 - admittedly for a shorter period - is rather disappointing. This

Table 2. Numbers of Monks associated with Welsh Cistercian Abbeys c.1300-c.1540

\begin{tabular}{|l|c|}
\hline Abbey & Number \\
\hline Aberconwy & 45 \\
\hline Basingwerk & 25 \\
\hline Cwmhir & 45 \\
\hline Cymer & 15 \\
\hline Dore & 115 \\
\hline Grace Dieu & 25 \\
\hline Llantarnam & 31 \\
\hline Margam & 58 \\
\hline Neath & 36 \\
\hline Strata Florida & 46 \\
\hline Strata Marcella & 34 \\
\hline Tintern & 99 \\
\hline Valle Crucis & 20 \\
\hline Whitland & 37 \\
\hline No house stated & 17 \\
\hline TOTAL: & $\mathbf{6 4 8}$ \\
\hline
\end{tabular}

19 I have attempted to remove any duplicates from these statistics. For example, a monk of one Welsh abbey who is known to have gone on to be the abbot of a different house (and even, in a few notable cases, later became abbot at yet another Welsh house) has been recorded once and listed under the earliest monastery.

${ }^{20}$ Williams, Welsh Cistercians, p. 127. 
low figure may be partly explained by the relatively poor survival of documentation for the Welsh Cistercians. For example, for the period under consideration, very few episcopal ordination lists survive from dioceses in Wales, ${ }^{21}$ though the ordination of some Welsh religious are recorded in English bishops' registers. Similarly, clerical subsidy lists for 1377-81, which provide an important snap-shot of monastic communities in England, survive for only three Welsh Cistercian houses. ${ }^{22}$ Lastly, for the period of the Dissolution, lists of pensions and capacities/ dispensations are preserved for a total of seven houses of white monks in Wales. ${ }^{23}$ However, in addition to the relatively poor rate of documentary survival for the Welsh Cistercians, those sources which do survive would suggest that the sizes of individual Welsh Cistercian communities had declined significantly since their heyday in the twelfth and early thirteenth centuries. ${ }^{24}$ The subsidy list for Whitland in 1377 refers only to the abbot plus six named monks, and the documents from 1539-40 would suggest that the community there was even smaller at the time of

${ }^{21}$ The notable exception is St Davids: R. F. Isaacson (ed. and trans.), The Episcopal Registers of the Diocese of St. David's 1397 to 1518, 2 vols (London, 1917). The extant registers for Bangor also contain a handful of ordination records: Arthur Ivor Pryce, 'The register of Benedict, bishop of Bangor, 1408-17', Archaeologia Cambrensis, 77 (1920), 80-107; idem, The Diocese of Bangor in the Sixteenth Century: Being a Digest of the Registers of the Bishops, A.D. 1512-1646 (Bangor, 1923). For the registers of the Welsh dioceses in general, see David M. Smith, Guide to Bishops' Registers of England and Wales: A Survey from the Middle Ages to the Abolition of Episcopacy in 1646 (London, 1981), pp. 25-9, 133-5, 179-87. Shaun McGuinness has recently completed a doctoral dissertation at Bangor University on the acta of the bishops of Bangor until 1306, and is now working on those of the bishops of St Asaph.

${ }_{22}$ London, The National Archives (hereafter TNA), E179/3/3 (Cymer), E179/21/1 and /16 (Whitland), and E179/21/8 (Cwmhir). In addition, an unnamed abbess, a handful of nuns plus one 'monk' of Llanllugan are named in TNA E179/1/6, probably for the year 1394 .

${ }^{23}$ Pension lists only exist for three Welsh Cistercian houses (Neath, Strata Florida and Whitland) because, as noted above, the others were dissolved in 1536-7 and therefore, except for the abbot/abbess, their inmates were not eligible for pensions. See Williams, Welsh Cistercians, pp. 78, 84-6. Dispensations were granted between 1536-40 to monks of these three houses, as well as those of Aberconwy, Dore, Margam and Tintern, and the abbot of Grace Dieu: D. S. Chambers (ed.), Faculty Office Register 1534-1549 (Oxford, 1966), pp. 38, 68, 80, 88, 91-3, 98, 100, 104, $170,206$.

${ }^{24}$ Glanmor Williams, Renewal and Reformation: Wales c. 1415-1642 (Oxford, 1993), p. 133. 
the dissolution. ${ }^{25}$ This stands in contrast to a claim by the abbey, made in the fourteenth century, that at the time of its foundation, the Whitland community had numbered up to 100 monks, though this may have been an exaggeration. ${ }^{26}$ Similarly, while Abbey Cwmhir allegedly housed between $50-60$ monks in the twelfth and early thirteenth centuries ${ }^{27}$ the subsidy roll for the archdeaconry of Brecon c.1381 records the names of only four monks. ${ }^{28}$ Surveys of the abbeys made in 1536 would support the view that the Welsh Cistercian communities, for the most part, fell well below the canonical minimum number of thirteen brethren (the abbot plus 12 monks). ${ }^{29}$ The difference between Williams's estimate of the total number of Welsh Cistercians and the much smaller figure of documented individuals discussed in the present paper may partly be a result of the relatively low rate of documentation but may also be a product of the decrease in the size of conventual communities in Wales after $c .1300$. Either way, it should be borne in mind that the statistics used in this paper by no means represent a complete picture of Welsh Cistercians and any conclusions drawn therefrom should be regarded as provisional.

I will offer separate analyses of the forenames and (so-called) surnames of the white monks in Wales, primarily after c.1300, and attempt to determine what these names may reveal about the ethnocultural perspectives of the relevant religious communities. ${ }^{30}$ In order to elucidate the possible significance of the names of these Welsh Cistercians, I will compare them with two other datasets: the names of

25 TNA E179/21/1; Chambers (ed.), Faculty Office Register, p. 206;TNA E315/233, fol. 258; J. S. Brewer et al., Letters and Papers, Foreign and Domestic, of the Reign of Henry VIII, 36 vols (London, 1862-1932), XIV/1, no. 747.

${ }^{26}$ Williams, Welsh Cistercians, p. 126.

27 Ibid.

28 TNA E179/21/8.

${ }^{29}$ Williams, Welsh Cistercians, p. 85, citing TNA LR6/151/1-2. There was a range however: at Grace Dieu in 1536 there were allegedly only the abbot and one monk, but at Tintern 12 monks of which the names of 11, including Abbot Wiche, are recorded in receipt of dispensations (Williams, Welsh Cistercians, p. 85; Chambers (ed.), Faculty Office Register, pp. 80, 91-2).

${ }^{30}$ In this paper, I will use the term surname to refer a hereditary family surname and, in contrast, byname to indicate a second name given to an individual which tells us something specific about him or her (such as his/her place of origin, name of father, appearance) and was therefore not inherited. Monastic byname will refer to a byname adopted by a member of a monastic order on admission or profession (see below). 
over 4,000 English monks and regular canons from 20 religious houses located in the diocese of Worcester during the same period, ${ }^{31}$ and also the names of just under 1,000 monks from seven English Cistercian houses located relatively close to the Welsh border. ${ }^{32}$ Thus, for the second dataset in particular, if there were any 'local' patterns of naming and recruitment, then the houses in Wales might share the pattern with these houses more than with those further afield. Indeed, a number of the English Cistercian houses had connections with Wales: for example, there was a small number of monks at these houses who bore 'Welsh' surnames, or etymologically English surnames common in Wales, and who perhaps had themselves joined the English houses from Wales or the Welsh borders. ${ }^{33}$ In addition we might recall that Kingswood was a daughter-house of Tintern Abbey, and Vale Royal was a daughter house of Dore. Vale Royal also held property in Wales ${ }^{34}$ and, as we shall see below, some Welsh Cistercian abbeys held property in England. These comparisons will serve to determine whether the Welsh Cistercians bore names that were, on the one hand, different from those of male religious in contemporary England in general, and more specifically from those of members of their own Order.

\section{THE FORENAMES OF WELSH CISTERCIANS}

All of the 648 Welsh Cistercians attested between 1300 and 1540 are recorded with their forenames. In the late Middle Ages, a monk or regular canon's forename was his given or baptismal name and not, as it is often the case today among Catholic religious clergy, a special monastic name adopted on profession. The forename therefore can reveal information about the bearer's - or more accurately, his parents' - socio-cultural

${ }^{31}$ Thornton, 'How useful'.

${ }^{32}$ These are: Combermere and Vale Royal, Cheshire; Hailes and Kingswood, Gloucestershire; Flaxley, Herefordshire; Buildwas, Shropshire; and Bordesley, Worcestershire. Of these, Bordesley, Hailes and Kingswood were located in the diocese of Worcester, and so occur in both non-Welsh datasets.

${ }^{33}$ Richard Evans (Bordesley, 1538), David ap Madok and John Lewys (both Buildwas in 1383); John Griffith and Thomas Hopkins (Hailes, 1539); William Hughes (Kingswood in 1538); and, at Vale Royal, John Lewis (1320), as well as John Banyon and Richard Benyon (in 1538).

${ }^{34}$ Williams, 'Cistercians in Wales: 2. Ceredigion', 269-70. 
context and identity. In the early Middle Ages, most of the populations of western Europe, and beyond, probably bore forenames that were formed from words or phrases in the language they spoke. Thus, while a limited number of Latin and Biblical names were not unknown, the so-called 'ethnicity' of an individual could generally be inferred from the linguistic origin of his or her forename. During the central Middle Ages, however, a small corpus of continental Germanic and Christian/saintly names came to predominate in many parts of western Europe, and this trend developed further during the late medieval period. ${ }^{35}$ These common forenames may have been pronounced slightly differently in different regions, and even written differently in the local vernacular languages, but they would have been written fairly consistently in Latin documents. Inferring ethnic identity from such names, especially in Latin, would be pointless therefore, though there were some local variations in the relative popularity of certain non-local or foreign forenames: in late medieval and early modern Scotland, for example, the names Alexander, Andrew and James were more popular than in England and Wales during the same period. ${ }^{36}$ Furthermore, in medieval Britain and Ireland, it was not-uncommon practice among scribes to render certain 'Celtic' forenames by means of more widely known English, Anglo-Norman or Latin 'equivalent' forms: for example, the Gaelic name Aodh may be rendered by some form of Hugh or less frequently as Odo; Donnchadh by Donatus; Giolla Brighde by Gilbert; and, Niall by Nigel. This practice could 'mask' the original Gaelic names, ${ }^{37}$ and by extension obscure the linguistic identity of the bearer of course. There are two ways therefore of associating a name with a particular region: firstly, whether the name itself is derived from the locally spoken language; and, secondly whether the forename, while not linguistically local, was notably popular in that region, either in itself or as an equivalent to a local name, and may therefore be considered local in a cultural sense.

35 See below, pp. 441-2.

36 On patterns of forenames in medieval Scotland in general, see Matthew Hammond, 'Introduction: the study of personal names in medieval Scotland', in idem (ed.), Personal Names and Naming Practices in Medieval and Early Modern Scotland (Woodbridge, 2019), pp. 1-17 (pp. 3-6).

37 Roibeard Ó Maolalaigh, 'Gaelic personal names and name elements in Scottish charters, 1093-1286', in Hammond (ed.), Personal Names, pp. 41-99 (pp. 46-7). 
Table 3 presents the most commonly attested forenames in the three datasets, as a percentage of all names in each dataset, and includes all names that occur at least 1 per cent in one or more of the datasets. The last row provides the same information for a group of linguistically Welsh forenames, even though none of these names individually exceeds 1 per cent of the Welsh Cistercian dataset.

The most obvious conclusion to be drawn from Table 3 is that over 90 per cent of white monks in Wales after c.1300 did not have a linguistically Welsh forename. Thus, if we were expecting to assign a Welsh 'identity' to monks - and by extension their respective abbeys - according to the linguistic origin of their forenames alone, then only about 8 per cent would be considered Welsh. The majority of the names in Table 3 represents the corpus of forenames of continental Germanic/

Table 3. The Most Common Forenames of Welsh Cistercians and Monks/ Canons in the Diocese of Worcester, 1300-1540 (as a percentage)

\begin{tabular}{|l|c|c|c|}
\hline Name & $\begin{array}{c}\text { Welsh Cistercians } \\
(\%)\end{array}$ & $\begin{array}{c}\text { Diocese of Worcester } \\
(\%)\end{array}$ & $\begin{array}{c}\text { Border Cistercians } \\
(\%)\end{array}$ \\
\hline Adam & 0.5 & 0.8 & 1.0 \\
\hline David & 7.0 & 0.2 & 0.3 \\
\hline Geoffrey & 1.2 & 0.2 & 0.4 \\
\hline Henry & 2.8 & 3.0 & 3.2 \\
\hline Hugh & 2.0 & 0.8 & 1.5 \\
\hline John & 27.0 & 29.0 & 25.7 \\
\hline Lewis & 2.0 & 0.0 & 0.0 \\
\hline Maurice & 1.0 & 0.09 & 0.0 \\
\hline Nicholas & 2.5 & 2.3 & 2.1 \\
\hline Philip & 1.2 & 0.8 & 0.4 \\
\hline Ralph & 0.5 & 0.5 & 1.3 \\
\hline Richard & 8.0 & 11.0 & 11.9 \\
\hline Robert & 3.7 & 6.0 & 6.8 \\
\hline Roger & 0.9 & 2.0 & 2.6 \\
\hline Thomas & 12.0 & 15.0 & 15.7 \\
\hline Walter & 2.2 & 3.1 & 2.3 \\
\hline William & 9.8 & 16.6 & 16.3 \\
\hline Welsh names & 8.2 & 0.05 & 0.0 \\
\hline
\end{tabular}


Norman or biblical/saintly origin that came, in varying degrees, to dominate naming in western Europe from the eleventh and twelfth centuries onwards. The similarity in the frequencies of the names of the Welsh Cistercians and those of monks and canons in contemporary England, as tabulated above, reflects this broader trend in European name-giving. The growing fashion towards linguistically non-Welsh names is apparent among the white monks of Wales if we compare the forenames of monks after 1300 with those before that year. Thus, of the 307 or so Welsh Cistercians who occur in Williams's lists before that date and whose forenames are known, as many as 22 per cent $(n=68)$ are recorded with linguistically Welsh forenames, and the other 78 per cent had the usual mixture of Anglo-Norman, continental and biblical names. This is almost three times more than the number after $c .1300$ when, as we have seen, only about 8 per cent of the monks and abbots bore etymologically Welsh names.

However, there are some notable differences in Table 3 that require further examination. The three most commonly attested forenames in the two English datasets (John, Thomas and William) are also the three highest scorers among Welsh white monks, but in each case the percentage is lower in Wales (significantly so for the name William). A number of other, less common forenames occur with very similar rates of frequency in all three datasets: notably, Henry and Nicholas. On the other hand, some names appear to have been significantly more frequent in one dataset or another: thus Robert, Roger and (as noted already) William seem to have been more popular in England; whereas David, Geoffrey, Hugh, Lewis, Maurice and Philip are more frequently attested among Welsh white monks, even though their overall frequencies in both England and Wales were relatively low. These differences were at least partly a product of slightly different naming patterns among the laity in England and those in Wales during the late Middle Ages.

For the period c.1300-1500, the most popular male forenames in England were consistently John, William, Thomas, Richard and Robert. ${ }^{38}$

38 David A. Postles, 'The baptismal name in thirteenth-century England: processes and patterns', Medieval Prosopography, 13/2 (1992), 1-52; Dave Postles, Naming the People of England, c. 1100-1350 (Newcastle, 2006) pp. 52-3, 74; Joel T. Rosenthal, 'Names and naming patterns in medieval England: an introduction', in Dave Postles and Joel T. Rosenthal (eds), Studies on the Personal Name in Later Medieval England and Wales (Kalamazoo, 2006), pp. 1-6 (pp. 4-5); Peter Franklin, 'Normans, saints and politics: forename choice among fourteenth-century Gloucestershire peasants', 
In the century or so after 1066, the fashion for using continental forenames had filtered down the social hierarchy, and names such as William, Richard and Robert gradually replaced the earlier AngloScandinavian forenames in England. During the thirteenth century, a number of previously less common names of saints increased in popularity. John came to challenge and eventually replace William as top name during the fourteenth century especially. The relative positions of Thomas (another latecomer), Richard and Robert could vary over time and space. This English pattern is reflected in Table 3 for the forenames of the religious from the diocese of Worcester and the English Cistercian monks. The growing popularity of the continental Germanic and Christian forenames was mirrored in Wales, partly after c.1100, and later after 1282-3, due to the immigration of settlers from England who used such given names, but also by the increasing adoption of these names by the native Welsh themselves, under English or possibly wider European influence. A number of scholars have discussed the patterns and distribution of forenames in Wales during the late Middle Ages and later. Melville Richards, for example, considered the relative frequencies of forenames in late medieval and early modern Wales, though he treated English and Norman-French names separately from 'Welsh' names and included Dafydd and Ieuan in the latter group. ${ }^{39}$ Of the Norman-French names, he found the most popular (in decreasing order of frequency) were John, Thomas and William, followed by Robert, Hugh and Richard. Of his Welsh names, the relative frequency was: Dafydd, Ieuan and then Gruffudd, followed by Madog, Iorwerth and Llywelyn. Peter Bartrum also offered a brief analysis of the forenames of the Welsh gentry as reflected in fifteenth-century genealogies. ${ }^{40} \mathrm{He}$ found the most popular names overall to be (again, in order): John, David, Thomas and Ieuan (equal), Gruffudd and then William. Interestingly, Bartrum's six most frequent male forenames combine the top three of Richards's two lists. ${ }^{41}$

in ibid., pp. 177-88; Virginia Davis, 'The popularity of late medieval personal names as reflected in English ordination lists, 1350-1540', in ibid., pp. 103-14.

39 Melville Richards, 'Gwŷr, gwragedd a gwehelyth', Transactions of the Honourable Society of Cymmrodorion (1965), 27-45 (33-8, 41-2).

40 Peter C. Bartrum, 'Personal names in Wales in the fifteenth century', National Library of Wales fournal, 22/4 (1981-2), 462-9.

${ }^{41}$ For an analysis of the frequency of forenames in nineteenth-century Wales, see John and Sheila Rowlands, The Surnames of Wales (2nd edn, Llandysul, 2013), p. 230. 
The frequency of forenames among the Welsh Cistercians after 1300 is notable therefore in that, on the one hand, it would seem to correlate more closely with the patterns of forenames in England except, on the other hand, for the relative popularity of the name David (though less popular than among the Welsh laity). ${ }^{42}$ The name David is significant here. Whether in its 'English' form, or as Dafydd or the hypocoristic Dai and Derwi, we may follow Melville Richards in considering David to be a Welsh name, in a cultural sense at least, like the saintly Andrew and royal Alexander and James in Scotland (above). Similarly, a handful of other medieval non-Welsh names may be regarded as culturally Welsh: for example, the group of forenames based on the English diminutive suffix -kin, such as Iankyn and Hopkyn - that were relatively common in parts of late medieval Wales and survive today as 'Welsh' surnames like Jenkins and Hopkins. ${ }^{43}$ Furthermore, there are a number of other 'Welsh' forenames that were in fact early adaptations of Latin-Christian names: notably, Ieuan as an early rendering of fohannes (as distinct from the later Welsh form Siôn) and also Meurig (OW Mouric) from Mauritius, Maurice. In addition, and like the Gaelic examples cited above, a number of linguistically Welsh names were often rendered in Latin documents by means of more common Continental Germanic or English names, especially by non-Welsh scribes: for instance, Hywel could be written using forms of Hugh (Latin Hugo), Llywelyn by Lewis (Lodovicus), and Iorwerth by Edward or, occasionally, Gervase. ${ }^{44}$ Indeed, it has been suggested that Richard (Ricardus) may sometimes mask the Welsh name Rhys, ${ }^{45}$ and I wonder if Geoffrey (Galfridus, etc.) could sometimes have replaced Gruffudd. ${ }^{46}$

42 Thus, it does not figure among the more commonly attested forenames in England in the data used by Postles, Davis, or Franklin cited above, n. 38.

43 O. J. Padel, 'Names in -kin in medieval Wales', in Della Hooke and David A. Postles (eds), Names, Time and Place: Essays in Memory of Richard McKinley (Oxford, 2003), pp. 117-26.

${ }_{44}$ T. J. Morgan and Prys Morgan, Welsh Surnames (Cardiff, 1985), pp. 19-21; Rowlands and Rowlands, Surnames of Wales, pp. 130, 155-6, 168, 183.

45 R. A. Griffiths, 'The poet as a social observer: Guto'r Glyn in west Wales', in Evans et al. (eds), 'Gwalch Cywyddau Gwŷr', pp. 135-47 (p. 137, n. 6).

${ }^{46}$ Thus, Gruffudd, abbot of Cymer around 1499-1500, is referred to variously as Griffith and Geoffrey, and in one document as Griffith 'by the name Galfrid': Smith et al., Heads, III, p. 287; Williams, Tudor Cistercians, p. 459. Gruffudd (Griffith) was very often rendered as Griffinus and variants in medieval Latin documents, and accordingly I have counted forms of Griffith and Griffin together in Table 3. 
If we wish to determine possible Welsh identity by means of the forenames of the Cistercians, therefore, I would suggest that, in addition to the obvious, linguistically Welsh names, we should also consider those which may be regarded as culturally Welsh and even those which, in some cases at least, may represent English/Latin equivalents of Welsh names. As Table 3 above shows, certain non-Welsh forenames, such as Geoffrey, Lewis and Maurice, and possibly Hugh, were indeed more commonly attested among the Welsh Cistercians than among the religious clergy in late medieval England. If this pattern is even partly due to the fact that these names were treated as equivalents of Gruffudd, Llywelyn, Meurig and Hywel, then we may consider these English forms as culturallyWelsh, at least potentially, along with David. Table 4 represents these three types of Welsh forename as a percentage of the attested names at each individual Cistercian abbey in Wales.

Table 4 shows that there was no consistent pattern of forenames among the brethren of late medieval Welsh Cistercian houses. At one extreme, we have Aberconwy Abbey, where over half the recorded monks

Table 4. Welsh (linguistically and culturally) Forenames among Welsh Cistercians, 1300-1540, as percentages for each abbey

\begin{tabular}{|l|c|c|c|c|}
\hline House & \%Welsh Names & \% David & \%Welsh Equivalent & \% Total \\
\hline Aberconwy & 15.5 & 24.4 & 13.3 & 53.2 \\
\hline Basingwerk & & & 4 & 4 \\
\hline Cwmhir & 26.6 & 6.6 & 6.6 & 39.8 \\
\hline Cymer & 20 & & 6.6 & 20.6 \\
\hline Dore & 0.9 & 1.7 & 2.6 & 5.2 \\
\hline Grace Dieu & & & & 0 \\
\hline Llantarnam & 12.9 & 12.9 & 3.2 & 29 \\
\hline Margam & 5.2 & 8.6 & 6.9 & 20.7 \\
\hline Neath & 11 & 5.5 & 2.7 & 19.2 \\
\hline Strata Florida & 21.7 & 15.2 & 6.5 & 43.4 \\
\hline Strata Marcella & 5.9 & 5.9 & 17.6 & 29.4 \\
\hline Tintern & & 1 & 5 & 6 \\
\hline Valle Crucis & & 10 & 10 & 20 \\
\hline Whitland & 16.2 & 16.2 & 10.8 & 43.2 \\
\hline
\end{tabular}

${ }^{\star}$ Welsh equivalent names $=$ Geoffrey, Hugh, Lewis and Maurice. 
bore forenames that were either linguistically or (possibly) culturally Welsh. In contrast, at Basingwerk, only 4 per cent of the known monks had potentially 'Welsh' given names, and all of these were non-Welsh forenames sometimes used as equivalents of Welsh names. The rates for the three different categories of 'Welsh' forename also vary between houses - for instance, at Abbey Cwmhir over a quarter of the attested monks bore linguistically Welsh names, which was well above the overall average for such names (8.2 per cent); but the percentage of monks at Cwmhir called either David or one of the 'equivalent' non-Welsh forenames was just $6.6 \%$ in each case. On the other hand, at Strata Marcella as many as 17.6 per cent of the forenames were 'equivalents' but only 5.9 per cent of the monks were called by linguistically Welsh names or David.

These comments aside, we may conclude from Table 4 that at certain Welsh Cistercian houses, a significant proportion of the monks' forenames may be considered to have been 'Welsh', linguistically and/or culturally: Aberconwy, Cwmhir, Strata Florida and Whitland. To these we could also add Llantarnam and Strata Marcella, and even Cymer (which had the second highest percentage of linguistically Welsh names, but no Davids). Conversely, at some monasteries none or very few of the brethren bore forenames that may be classified as Welsh: notably, Basingwerk, Dore, Grace Dieu and Tintern. It is tempting to include Valle Crucis among these too, as no recorded monk at that house bore a linguistically Welsh forename, but the number of brethren called David and an 'equivalent' names is relatively high (10 per cent each).

However, forenames only tell half the story, and we must also examine the apparent 'surnames' of the Welsh white monks in order to gain a fuller understanding of the anthroponymy of the Order in Wales.

\section{THE SURNAMES OF WELSH CISTERCIANS}

Of the 648 monks known to have occupied Welsh Cistercian houses between 1300 and 1540, 115 are recorded with the forenames only. Of the remaining 533 monks, I have been able to analyse the surnames/ bynames of 513 , using the typology normally applied to British surnames discussed in more detail below. Table 5 summarises the basic analysis of the names of these 513 men, and compares them with the typology of surnames of religious in the diocese of Worcester and the seven Cistercian monasteries located near the Welsh border. 
Table 5. Typology of Surnames of Welsh Cistercians and English Monks/Canons, c.1300-1537

\begin{tabular}{|l|c|c|c|}
\hline Name Type & \% Welsh Cistercians & \% Diocese of Worcester & \% Border Cistercians \\
\hline Ethnic term & 0.0 & & 0.2 \\
\hline French name/word & 1.4 & 2.6 & 2.0 \\
\hline Nickname & 10.5 & 1.9 & 1.9 \\
\hline Occupation & 3.9 & 2.3 & 5.4 \\
\hline Personal name & 35.6 & 6.5 & 5.1 \\
\hline Topography & 0.9 & 6.5 & 3.0 \\
\hline Place name & 47.7 & 80.1 & 82.4 \\
\hline
\end{tabular}

What is immediately apparent from Table 5 is the very different distributions of types of surname among the late medieval Welsh Cistercians and the regular clergy in contemporary England. Among the English monks and canons more than 85 per cent of surnames seem to have been derived from place-names and/or topographical features, whereas less than half of the names in the Welsh dataset follow this pattern. In contrast, over $35 \%$ of the Welsh Cistercian monks bore 'surnames' based on personal names, which account for only 6.5 per cent and 5.1 per cent of names in the two English datasets; and, similarly 10 per cent of the Welsh monks had names derived from nicknames, whereas these amount to less than 2 per cent in England. This very distinct contrast between the surnominal typology of white monks in Wales and the regular clergy in England can, I think, be explained partly by the very different systems of naming among the late medieval English and Welsh in general, and partly because of the practice among English monks and canons of adopting special 'monastic bynames'.

In order to make sense of the naming of monks in Wales and England during the late Middle Ages, some comments should be ventured about the development of hereditary surnames in these two regions. The idea of an inherited family surname was first introduced into England following the Norman Conquest but remained the preserve of a (mostly aristocratic) minority until the middle of the thirteenth century by which time most English landowners had adopted (more or less) fixed surnames. ${ }^{47}$ However,

47 Patrick Hanks, Richard Coates and Peter McClure (eds), The Oxford Dictionary of Family Names in Britain and Ireland (Oxford, 2016), I, pp. xxiv-xxv; R. A. McKinley, 
the greater part of the English population continued to be known by their forename plus an additional individual byname that served to distinguish the bearer from his or her namesakes, such as the name of the bearer's father, his place of origin or occupation, or some aspect of the bearer's appearance or behaviour. It was only during the first half of the following century that the less wealthy rural and urban families in the south of England used inherited surnames with any frequency, and not until the first half of the fifteenth century that the practice became well established in the north. For the most part, English surnames are based upon the different types of byname mentioned above which over time became 'fixed' and inherited: as well as a small number surnames of French/Norman origin, these include place-names (the village from which the first bearer may have come), occupations or status (of the first bearer), patronymics (the forename of the first bearer's father or, very rarely, mother), and nicknames (describing some aspect of the appearance or behaviour of the first bearer). Although the relative distribution of these different types could vary over time and space, it was rare for one type to account for more than 40 per cent of the surnames in a given locality. ${ }^{48}$

The situation in late medieval Wales was not only different from that in England but rather more complicated as well. ${ }^{49}$ Most medieval Welsh men and women did not have a hereditary surname but rather, since the early Middle Ages, the Welsh had, like the Irish, traditionally used a patronymic system of naming: that is, a man was known by his forename followed the noun map, 'son', later $a p$ and before a vowel $a b$, and then

A History of British Surnames (London and New York, 1990), pp. 25-39; Percy H. Reaney, The Origin of English Surnames (London, 1987).

${ }^{48}$ Richard McKinley, Surnames of Lancashire (London, 1981); idem, History of British Surnames, pp. 22-3; David Postles, The Surnames of Devon (London, 1995); idem, The Surnames of Leicestershire and Rutland (Oxford, 1998); Reaney, Origin of English Surnames, pp. 22-3.

${ }^{49}$ See Prys Morgan, 'The rise of Welsh hereditary surnames', Nomina, 10 (1986), 121-35; McKinley, History of British Surnames, pp. 39-44; Hanks et al. (eds), Oxford Dictionary of Family Names, I, pp. xxx-xxxi; John and Sheila Rowlands, 'The transition from patronymic names to settled surnames in Wales', Nomina, 28 (2005), 55-68; Morgan and Morgan, Welsh Surnames, pp. 13-24; Prys Morgan, 'The rise of Welsh surnames in Carmarthenshire', The Carmarthenshire Antiquary, 46 (2010), 73-9; D. Petley-Jones, 'The change from patronymics to surnames in rural Montgomeryshire', Genealogists Magazine, 26, 12 (2000), 473-4; Sheila Rowlands, 'The surnames of Wales', in John Rowlands and Sheila Rowlands (eds), Welsh Family History: A Guide to Research (Birmingham, 1998), pp. 59-75; Rowlands and Rowlands, Surnames of Wales. 
his father's name, as in the case of Llywelyn ab Ieuan, monk of Whitland Abbey in $1377 .{ }^{50}$ Welsh women were normally known as merch (lenited as ferch), 'daughter', of their father. Occasionally, individuals were recorded with more than one ancestor: for example, David ab Ieuan ab Iorwerth, who was abbot of Valle Crucis, 1480-1503, and possibly previously monk of Aberconwy. ${ }^{51}$ Medieval Welsh patronymics, as well as laterWelsh patronymic surnames, took a variety of forms. ${ }^{52}$ The basic form was the 'ap/ab phrase' described above: thus, a little over half the Cistercian monks with patronymics were named in this manner, and are attested throughout the period 1300-1540. It was also relatively common for the forename of the bearer's father to be given alone, without 'ap/ab' and, among the Cistercians, this form becomes more commonly attested during the fifteenth century: for example, John Philip, monk of Abbey Dore, ordained acolyte and deacon in 1450, and Einion David, monk of Margam ordained priest in $1487 . .^{53}$ Alternatively, the addition of the English genitive suffix $-s$ to the father's name, usually without 'ap/ab' (but see below), became common and survives in a number of common Welsh surnames (notably Jones and Williams). Among the Cistercians, this type of patronymic is mostly attested in the sixteenth century (except for 3 cases from 1460s): for example, Thomas Rogers ordained as monk of Abbey Dore in 1461, and Geoffrey Johns who was abbot of Aberconwy in $1525-35 .{ }^{54}$ However, there were a number of forenames frequently used in late medieval Wales that themselves ended in a final $-s$ and so, as patronymics, may be treated as simple names or may have assimilated the genitive $-s$ (Lewis, Morris, Rhys, Thomas): Cistercian instances include John Morris, cellarer of Tintern abbey in 1411-12, and William Lewis of Margam in $1426 .{ }^{55}$ Finally, a number of Welsh patronymic surnames have resulted from the prefixing of $P-/ B$-, reduced from 'ap/ab', to the following personal name (Bowen, Parry, Powell, Price): such forms are rare and attested late among the Welsh Cistercians, but include Robert Price, monk of Dore, $c .1496 .{ }^{56}$ The relatively late use of the $-s$ suffix

50 TNA E179/21/1.

51 Smith, Heads, III, p. 344; Williams 'Fasti' (2014), 196.

52 Morgan and Morgan, Welsh Surnames, pp. 10-24; and Rowlands and Rowlands, Surnames of Wales, pp. 9-17, 33-6, 50-8.

${ }^{53}$ Williams, 'Fasti' (2014), 197, 215.

54 Ibid., pp. 207, 218; Smith, Heads, III, p. 285.

55 Williams, 'Fasti' (2014), 209, 213.

56 Ibid., 216; Williams, Tudor Cistercians, p. 506. 
and the $P$ - prefix to form patronymics need not indicate that the bearer had a hereditary surname as opposed to a true patronymic. ${ }^{57}$ Indeed, the distinction between these different ways of forming the patronymic was not absolute, and there were a number of Welsh Cistercians whose names were recorded in more than one manner in different sources. Thus, the Owain David, monk of Cwmhir ordained acolyte on 27 May 1458, was presumably the Owyn ap David of the same abbey who was ordained priest in March of the following year. ${ }^{58}$ More extreme, there was a monk of Margam ordained 1497x1501 whose name is variously recorded as Thomas ap Harry, Thomas Harry and Thomas Harries. ${ }^{59}$ One of the last monks of Strata Florida was ordained in 1532 as Morgan Johns and received his dispensation in the Faculty Office Register with the same name-form, but in the pension list he is recorded as Morgan 'ap Johns', thus combining the Welsh $a p$ with the English genitive suffix. ${ }^{60}$ As stated above, the Welsh patronymic system persisted, at least in the Welsh-speaking areas, until comparatively recently.

Occasionally, some medieval Welshmen were also recorded in documents with an individual byname or epithet, not dissimilar to those found earlier in England, either along with or even instead of their patronymic: the majority of these seem to have been adjectival nicknames, describing the appearance of the bearer, but occupations and places of origin were not unknown. However, the use of such nicknames was relatively infrequent: for example, the research of Peter Bartrum - drawing upon genealogical rather than the administrative and testamentary sources usually employed by students of medieval names would suggest that about 7.5 per cent of the Welsh gentry in the fifteenth and early sixteenth centuries were known by some kind of descriptive adjective. ${ }^{61} \mathrm{~A}$ number of Welsh nicknames eventually became fixed and survive today as surnames: the most common include llwyd, 'grey', which

57 Morgan and Morgan, Welsh Surnames, p. 18.

58 A.T. Bannister (ed.), Registrum Fohannis Stanbury, Episcopi Herefordensis, A.D. 1453-1474 (London, 1919), pp. 142, 144.

59 Isaacson (ed.), Episcopal Registers, II, pp. 718, 734; WRO MS b706.093BA2648/7(iii) (Reg. G. de Gigli), fol. 27r.

${ }^{60}$ A.T. Bannister (ed.), Registrum Caroli Bothe, Episcopi Herefordensis, A. D. MDXVIMDXXXV (Hereford, 1921), p. 329; Chambers (ed.), Faculty Office Register, p. 206; TNA E315/233, fol. 219.

${ }^{61}$ P. C. Bartrum, 'Cognomens in Wales in the fifteenth century', National Library of Wales fournal, 30/2 (1997), 133-6. 
gave Lloyd, goch, from coch, 'red, red-haired', gave Gough, and fychan, from bychan, 'small, the younger (for namesakes)', gave Vaughan; we might also note Sais, lit. Englishman but maybe also a man who spoke English, which gave Sayce. ${ }^{62}$ However, in the late medieval period, it is likely that, in most cases, such nicknames still functioned as individual bynames rather than as hereditary surnames and that was probably the case for those Welsh Cistercians who bore such names. In contrast to the stereotypical Welsh usage of occupational nicknames ('Jones the Post'), the use by the late medieval Welsh of occupational epithets seems to have been very rare and as a consequence there are comparatively few Welsh occupational surnames. ${ }^{63}$ Thus, the names of Welsh Cistercians derived from occupations form a very small part of the corpus collected by Williams, numbering at most about twenty individuals. Furthermore, almost all of these names are of English origin and were therefore probably English occupational surnames. ${ }^{64}$ From Williams's corpus, only John Sere/Seere, monk at Whitland in 1425-6, and Thomas Sayer, Grace Dieu in 1481, may have borne a Welsh occupational name (from Welsh saer, 'carpenter, wright'), though alternative English and (ultimately) French sources for these forms may also be postulated. ${ }^{65}$ Finally, locative bynames were relatively rare among the late medieval and early modern Welsh, and the number of Welsh surnames derived from place-names and/or topographical features remains low today. Bartum's figures would suggest about 3.5 per cent men named in the fifteenth-century genealogies had some sort of locative cognomen.

However, the patronymic system, supplemented by the occasional use of adjectival, occupational and locative bynames, was not the only personal naming system in Wales during the high and later Middle Ages. The Anglo-Norman penetration into Wales during the late eleventh and early twelfth centuries, especially in the south-east and north-east of

${ }^{62}$ Morgan and Morgan, Welsh Surnames, pp. 25-6; Morgan, 'The rise of Welsh hereditary surnames', pp. 127-8; T. E. Morris, 'Welsh surnames in the border counties of Wales', Y Cymmrodor, 43 (1932), 93-173 (117-30); Rowlands and Rowlands, Surnames of Wales, pp. 19-23; Bartrum, 'Cognomens', 135.

${ }^{63}$ Rowlands and Rowlands, Surnames of Wales, pp. 23-5; Robert A. Fowkes, 'Welsh surnames of occupational origin', Names: A fournal of Onomastics, 41, 4 (1993), 288-97; Bartrum, 'Cognomens', 134.

${ }^{64}$ For example, Baker, Barber, Bishop, Butler, Clerk, Franklin, Fisher, Mason, Porter, Smith and Walker.

${ }^{65}$ McKinley, History of British Surnames, p. 151; Morgan and Morgan, Welsh Surnames, p. 189. 
Wales and Pembrokeshire, and the creation of the Welsh March, as well as the later military and administrative incursions during the Edwardian conquest and settlement at the end of the thirteenth century, involved the arrival in various parts of Wales of immigrants, mostly from England, bringing with them their own language and system of naming. Thus, Wales came to have two (initially) distinct naming traditions or what Heather Jones has termed name communities ('a relatively homogeneous population using the same name pool in the same way'). ${ }^{66}$ In those areas and towns settled significantly from England (the 'Englishry'), we find the use of English surnames by the settlers and the coining of new surnames by the descendants of the settlers modelled on the English system described briefly above. Cistercian examples include the troublesome, penultimate abbot of Valle Crucis, Robert Salusbury (1527/8-35), whose Welsh gentry family and their surname probably derived originally from Herefordshire.$^{67}$ In those parts of Wales that remained relatively free of English colonisation, the Welsh patronymic system of naming prevailed well into the early modern period and persisted, in some remote rural areas, into the nineteenth century. The adoption of hereditary surnames by the Welsh therefore came late and developed gradually. By the late fourteenth and fifteenth centuries, only a small number of Welsh families, mostly those living near or over the English border and those working in English service, had started using hereditary surnames. During the sixteenth century, the major Welsh landowning/gentry families had taken surnames - such as the Pennants who provided the last two abbots of Basingwerk (see below) - but most of the Welsh population would not do so for about another two hundred years, especially in the west of Wales. Furthermore, when the Welsh did adopt surnames, their surnames tended to be predominantly patronymic in character, derived from the earlier Welsh patronymic system of naming. Thus, as seen above, only a few Welsh surnames are derived from place-names and these are mostly to be located in those areas that experienced English influence and/or settlement. ${ }^{68}$ Welsh nickname or descriptive surnames are mostly limited

${ }^{66}$ Heather Jones, 'Comparing historic name communities in Wales: some approaches and considerations', in Postles and Rosenthal (eds), Studies, pp. 211-76.

67 D. Huw Owen, 'The Englishry of Denbigh: an English colony in medieval Wales', Transactions of the Honourable Society of Cymmrodorion (1974-5), 57-76 (72).

68 Morgan and Morgan, Welsh Surnames, pp. 27-31; Prys Morgan, 'Locative surnames in Wales: a preliminary list', Nomina, 14 (1990-1), 17-23; idem, 'The place-name as surname in Wales', in Della Hooke and Dave Postles (eds), Names, 
to colours and are comparatively rare, and occupational surnames that is names derived from Welsh words for an occupation, as opposed to English occupational surnames used in Wales - are virtually nonexistent. ${ }^{69}$ For the period of the current study (c.1300-1540), therefore, we may distinguish very broadly two name communities in Wales: one in which the English system of surnaming and English surnames would have prevailed, among the descendants of English settlers and, to some extent, those Welsh living and working in areas of such settlement and also latterly the Welsh upper gentry; and the other, in which the traditional Welsh patronymic system persisted and individuals were distinguished by a forename and their father's name and even grandfather's name, and/or occasionally by use of an additional nickname byname.

However, while the idea of equating Welsh patronymics and Welsh-language nicknames with Welshmen may seem reasonable, the corresponding identification of other categories of 'surname' (especially place-names) with the English and the Englishry in Wales cannot be sustained. As Table 5 shows, over 80 per cent of the monks and canons in the two English datasets bore toponymic and topographical names: this figure is not only different from that for the Welsh Cistercians but also from what we expect of surnominal distribution among the laity in contemporary England. In fact, historians have long acknowledged that many, though certainly not all, male members of monastic orders in England, from at least c.1300 (and possibly earlier) down to the dissolution of the monasteries in the period 1536-40, seem to have ceased using their hereditary family surnames on entering religion, and to have adopted instead a different 'surname', what I have called elsewhere 'monastic byname'. ${ }^{70}$ For the fourteenth and fifteenth centuries these monastic bynames were almost exclusively locative in character: derived mostly from place-names (toponyms) or topographical features. The use of toponyms as monastic bynames was widespread throughout England

Time and Place: Essays in Memory of Richard McKinley (Oxford, 2003), pp. 101-16; O. J. Padel, 'Locational surnames in fourteenth-century Denbighshire', in Alexander R. Rumble and Anthony David Mills (eds), Names, Places and People: An Onomastic Miscellany in Memory of Fohn McNeal Dodgson (Stamford, 1997), pp. 279-300; also Morris, 'Welsh surnames', pp. 130-5.

${ }^{69}$ Fowkes, 'Welsh surnames of occupational origin'.

70 David E. Thornton, 'Locus, sanctus et virtus: monastic surnaming in late medieval and early Tudor England reviewed', fournal of Medieval Monastic Studies (forthcoming). 
for most of the later Middle Ages: only after c.1490 do we find the adoption of some non-toponymic bynames by monks in the south of England and also the retaining of family surnames by some religious, especially regular canons, in the north. Furthermore, historians have generally assumed that, as monastic bynames, toponyms were derived from the place of birth or recent origin of their bearers. ${ }^{71}$

The evidence presented in Table 5 above suggests that the 'surnames' of Welsh Cistercians, taken altogether, did not follow the predominantly patronymic naming among the Welsh, yet neither did they conform to the usage of monastic bynames as evidenced among religious clergy in contemporary England. While the overall pattern of names of late medieval Welsh Cistercians was clearly different from that which prevailed among their English counterparts, there were also differences in naming between Welsh monasteries. Thus, if we analyse the distribution of the two main types of surname/byname - toponyms and patronyms - as well as nicknames by individual monastery, it can be seen that some Welsh Cistercian houses conformed, more or less, to the overall pattern as outlined in Table 4 above, but at others, there is significant divergence from the general pattern. This is illustrated in Table 6, with the percentage of toponymic and patronymic names, and of nicknames.

As noted above, the respective sizes of the monastic communities at the Welsh Cistercian houses in the late Middle Ages varied and in addition the total number of monks who had a 'surname' recorded for individual houses varied significantly too. Therefore, the percentages in Table 6 for the less well-documented houses, based on so few names, may not of course be as representative as those for Dore and Tintern. However, some comments may be ventured. On the one hand, we see a number of Welsh Cistercian houses where over half $(59 \times 78 \%)$ the attested surnames/bynames are toponymic: Strata Marcella, Tintern, Basingwerk and Dore. On the other hand, certain houses produced a similar percentage-range of patronymic names (54x71\%): Aberconwy, Cwmhir, Margam, Neath and Whitland. In between these two groups are the remaining houses where neither name-type exceeds 50 per cent (range 30x45\%): Cymer, Llantarnam, Strata Florida and Valle Crucis. Finally, at Grace Dieu we see that neither toponyms nor patronyms exceed 50 per cent, due to the occurrence of other surname types

71 Thornton, 'Locus, sanctus et virtus'; David Knowles, The Religious Orders in England, 3 vols (Cambridge, 1948-59), II, pp. 231-2. 
Table 6. Toponymic, Patronymic and Nickname

Surnames (as \%) at Welsh Cistercian Abbeys

\begin{tabular}{|l|c|c|c|}
\hline Abbey & Toponymic Name (\%) & Patronymic Name (\%) & Nickname (\%) \\
\hline Aberconwy & 16 & 55 & 23 \\
\hline Basingwerk & 66 & 7 & 7 \\
\hline Cwmhir & 20 & 60 & 19 \\
\hline Cymer & 40 & 40 & 18 \\
\hline Dore & 78 & 11 & 6 \\
\hline Grace Dieu & 48 & 14 & 10 \\
\hline Llantarnam & 41 & 45 & 6 \\
\hline Margam & 19 & 62 & 17 \\
\hline Neath & 21 & 71 & 5 \\
\hline Strata Florida & 29 & 47 & 6 \\
\hline Strata Marcella & 59 & 36 & 19 \\
\hline Tintern & 75 & 13 & 17 \\
\hline Valle Crucis & 44 & 31 & 8 \\
\hline Whitland & 16 & 54 & 83 \\
\hline No house & 0 & & 6 \\
\hline
\end{tabular}

(occupational and French-derived names), yet toponymic names account for more than twice the number of patronyms, perhaps putting this house with the first group. Nicknames account for about 10 per cent of the 'surnames' of the Welsh Cistercians as a whole - a lot higher than among English monks and canons - but when analysed individually we see a similar variation between monasteries. Thus, there was a relatively high proportion of nicknames at houses where patronymics predominate: especially Aberconwy, Cwmhir and Whitland. On the other hand, some houses with many patronymics produced relatively few nickname surnames, notably Margam and Neath.

\section{DISCUSSION}

To what extant, then, can the onomastic data presented above reveal the origins and 'ethnicity' of their individual monkish bearers and, 
by extension, their respective religious houses? Anthropologists and sociologists have long recognised that concepts such as ethnicity, ethnic identity and self-identification are by no means fixed and objective phenomena but rather individual social and psychological constructs that are fluid and dependent on personal circumstances and choice. ${ }^{72}$ Given the degree of fluidity and subjectivity, can one even presume to recognise ethnicity in the historical record? In turn, personal names and naming are affected by social and cultural influences, and thereby prone to change over time. ${ }^{73}$ Determining the 'ethnic self-identification' of the Welsh Cistercians by analysing their personal names is by no means a simple or straightforward process therefore.

Tables 4 and 6 above demonstrate that the relative frequency of different types of forename and 'surname' varied between individual Welsh Cistercian monasteries. Table 4 shows that those forenames that may be considered linguistically and especially culturally Welsh were far more commonly borne by monks of certain houses than at others. Similarly, in Table 6 we see that the use of Welsh patronymics and nicknames was significantly frequent at particular houses, whereas toponymic 'surnames' - probably comparable to monastic bynames at English monasteries - were more frequent at certain other houses. Furthermore, if we compare the evidence of these two tables, it can be seen that, up to a point, the relative frequency rates for both 'Welsh' forenames and patronymics/nicknames are similar at the same individual monasteries. Thus, we find the highest frequency of both Welsh forenames (range: $40 \times 55 \%$ ) and patronymics/nicknames (range: $60 \times 80 \%$ ) at Aberconwy, Cwmhir, Strata Florida, and Whitland. Conversely, the monasteries with the lowest frequencies of Welsh forenames $(0 \times 10 \%)$ are also those houses where toponymic surnames/bynames are most frequently found (45x75\%): Basingwerk, Dore, Grace Dieu, and Tintern. In addition, there are some abbeys where Welsh forenames are attested not infrequently but hardly predominate (20-30\%) and also where the patronymics/nicknames and toponyms both fall within the range 40x50\%: Cymer, Llantarnam and Valle Crucis. However, there are also

72 Miri Song, Choosing Ethnic Identity (Malden MA, 2003); Joanne Nagel, 'Constructing ethnicity: creating and recreating ethnic identity and culture', Social Problems, 41 (1994), 152-76; Stephen Cornell and Douglas Hartmann, Ethnicity and Race: Making Identities in a Changing World (Thousand Oaks, CA, 1998).

${ }^{73}$ On fashion and naming, see Stanley Lieberson, A Matter of Taste: How Names, Fashions, and Culture Change (New Haven, CT, and London, 1988). 
some houses where the relative frequencies of the two types of name do not seem to correlate so conveniently. Thus, at Margam and Neath, Welsh forenames fall within the lower end of the middling range (20 per cent) and yet patronymics and nicknames are attested very frequently (68 per cent and 75 per cent respectively). Similarly, at Strata Marcella, the Welsh forenames were also middling (29.4 per cent) but toponyms fall just under the highest range (59 per cent). Overall, though by no means absolutely, the relative frequencies of so-called forenames and of patronymics and/or nicknames at most Welsh Cistercian monasteries would suggest that, when taken together, the two types of onomastic data may be used to reflect some sense of Welsh ethnic identity of the monks at certain houses and the apparent lack of such an identity at some others.

Comparison of the onomastic data presented above with the evidence for Welsh cultural activity at individual Cistercian monasteries would seem to indicate that, broadly speaking, most of those abbeys where the forenames and/or 'surnames' of the inmates may be described as Welsh were also among those houses where native Welsh poets found abbatial patrons and where Welsh and Cambro-Latin texts were composed or copied during the late Middle Ages. This is especially the case at Aberconwy, Whitland and Strata Florida. Conversely, those Cistercian houses with no known Welsh cultural associations (Grace Dieu, Tintern and, not surprisingly perhaps, Abbey Dore) were also those where very few or no forenames of their monks may be considered linguistically or culturally Welsh and/or where the use of toponymic bynames prevailed. However, the correlation between cultural and onomastic evidence is by no means perfect, and it seems likely that other factors were at play. As we have seen, Basingwerk and especially Valle Crucis both figure among those monasteries that produced Welsh-language manuscripts and attracted the attention of poets. However, the onomastic evidence for these two houses would, on the face of it, suggest a less Welsh character among their monks. Basingwerk Abbey in particular has been recognised for its 'Englishness': ${ }^{74}$ as we have seen, no recorded monks of the abbey had linguistically Welsh forenames and about two-thirds bore toponymic surnames/bynames (more in fact than at Grace Dieu). For Valle Crucis, the onomastic evidence is perhaps less pronounced:

${ }^{74}$ David H. Williams, 'The monks of Basingwerk: foreigners in Wales?', Flintshire Historical Society fournal, 39 (2012), 33-53 (50). 
linguistically or culturally Welsh forenames account for about 20 per cent of the total recorded, and the number of recorded toponyms is about the same as that of patronymics and nicknames put together. From a naming perspective, the monks of Valle Crucis Abbey were not as 'English' as their confreres at Basingwerk and yet were definitely less 'Welsh' than those at Aberconwy, Strata Florida, and Whitland. How may we explain therefore that, despite their seemingly English recruitment, during the fifteenth century Basingwerk and Valle Crucis abbeys - and notably the latter - were active in the production of Welsh manuscripts and the patronage of Welsh poetry?

As shown in Table 2 above, both Basingwerk and Valle Crucis are among those Cistercian houses for which the names of relatively few monks have survived in the written record. Perhaps the extant samples are too small to be of statistical value. On the other hand, at both abbeys it would seem that the promotion of particular individuals as abbot may have had a significant impact on the 'character' of the respective houses. At Basingwerk, the dominance of English abbots was ended c.1481 with the appointment of the Welshman Thomas Pennant, who was in turn succeeded by his own son Nicholas Pennant. Abbot Thomas in particular was a patron of Welsh literary culture and the object of Welsh bardic praise, notably by Gutun Owain and Tudur Aled, as well as Siôn ap Hywel ap Llywelyn Fychan. He was also a close relative of the scribe of MS Peniarth 182, Syr Huw Pennant, whom the abbot may have mentored. ${ }^{75}$ However, the handful of ordination records of monks of Basingwerk that survive for this later period do not suggest that the recruitment pattern at the abbey had changed significantly: of four monks ordained by bishops of Coventry and Lichfield, all bore toponymic bynames and only one of these (Chirk) may be associated with certainty with a place in Wales. ${ }^{76}$ In the case of Basingwerk therefore the abbey's strong association at the end of the fifteenth century with Welsh culture was not necessarily reflected in its conventual personnel but may be explained with reference to the personal interests of one abbot in particular. At Valle Crucis, John ap Richard, of the local Trefor family, was appointed abbot $c .1455$, followed by the promotion from

${ }^{75}$ Jane Cartwright, Hystoria Gweryddon Yr Almaen: The Middle Welsh Life of St Ursula and the 11,000 Virgins (Cambridge, 2020), pp. 32-3.

${ }^{76}$ Stafford, Staffordshire Record Office, MSS B/A/1/12 (Reg. Hales), fols. 217v, 228-29, 231, 247v-249r, and B/A/1/13 (Reg. Smith and Arundel), fols. 271, 272v, $274 \mathrm{v}, 287 \mathrm{r}$. 
Aberconwy in 1480 of Dafydd ab Ieuan ab Iorwerth, who was in turn succeeded by another Welshman, John Lloyd. ${ }^{77}$ It was during the rule of these men that Valle Crucis and its abbots attracted the attention of the Welsh poets Gutun Owain (nephew of Abbot John ap Richard), Guto'r Glyn, and Tudur Aled as well as Lewys Môn, Dafydd ab Edmwnd, Dafydd Cowper and Gruffudd ab Ieuan. Of the handful of monks who were ordained - and therefore presumably admitted - during the rule of these Welsh superiors, most (but not all) bore toponymic bynames. ${ }^{78}$ As at Basingwerk, the influence of Welshmen as abbot did not reduce the 'English' practice of adopting toponyms.

The importance of Cistercian abbeys for Welsh culture, and especially for the patronage of Welsh poetry, may partly have been a product of the fact that there were simply more houses of white monks in Wales than of any other order. Fifteenth- and sixteenth-century Welsh bards in fact composed praise poetry for a wide variety of Welsh and also English patrons, including senior members of the secular clergy, monastic superiors of other religious orders, and even abbots of monasteries in England. Thus, for example, Guto'r Glyn wrote a poem in praise of Thomas Ludlow, abbot of Shrewsbury (1433-59), and Tudur Aled composed an awdl for John Birkenshaw, abbot of St Werburgh's, Chester (1529-38). ${ }^{79}$ Both these men, we should note, were Benedictines,

77 Smith, Heads, III, p. 344; Williams, Welsh Cistercians, p. 298. The dates of John Lloyd's abbacy are somewhat unclear. David Williams generally favours the range $1503 \times 1527$ (Welsh Cistercians, pp. 66, 298; 'Fasti' (2014), p. 210; Tudor Cistercians, p. 486), though the end-date is usually accompanied by a question mark. The year 1503 is in fact derived from an unsourced reference in G. Vernon Price, Valle Crucis Abbey (Liverpool, 1952), p. 48. On the other hand, David Smith cites the most recent reference to Abbot John in office as 1514: Heads, III, 344. It is perhaps worth recalling however that, in his will dated 12 April 1527, the poet Lewys Môn made bequests of 20 shillings both to 'John, abbot of Valle Crucis' and to 'the convent of the same place for prayers for my soul': TNA PROB 11/22/358 (the will is not lost, as commonly stated); printed incompletely by D. R. Thomas in 'Extracts from old wills relating to Wales ', Archaeologia Cambrensis, 4th series, 11, 43 (1880), 217-20 (p. 218); see also Eurys I. Rowlands, Gwaith Lewys Môn (Cardiff, 1975), p. xi. Abbot John is also mentioned in the probate clause (28 June 1527), and if this abbot was John Lloyd, then Williams's dating is presumably to be preferred.

78 Stafford, Staffordshire Record Office, MSS B/A/1/13, fol. 281v, and B/A/1/14 (Reg. Blyth), no fol. (date: 18.9.1507; 2.6.1512, 1514).

${ }^{79}$ Guto'r Glyn, 'Moliant i'r Abad Tomas o Amwythig', Guto'r Glyn.net <http:// gutorglyn.net/gutorglyn/poem/?poem-selection=077>. Tudur Aled, 'Un tad yn abad, wynebwr grasus': 'Abbot Thomas of Shrewsbury, fl. c.1433-d. 1459', Guto'r Glyn.net, 
though it has also been suggested that they both had Welsh family connections. ${ }^{80}$ Furthermore, as Glanmor Williams pointed out, not all the poets were unwavering in their commitment to the religious orders and to the Cistercians in particular. Lewys Morgannwg, for example, was fulsome in his praise for Neath Abbey and its last superior, Lleision ap Thomas, but would later applaud Henry VIII for the suppression of what he termed the 'false religious of the choir' ${ }^{81}$ In some cases, as we have seen at Basingwerk and Valle Crucis, it may have been particular individuals, rather than the office of abbot or the Cistercian ethos in general, that attracted the attention of the poets. Perhaps most notable is the important figure Dafydd ab Owain, monk of Strata Marcella, whose career between 1485 and 1513 saw him made abbot successively at Strata Marcella, Strata Florida and finally Aberconwy, which he held in commendam after becoming bishop of St Asaph in 1503, as well as being sometime provisor at St Bernard's College, Oxford. ${ }^{82}$ Abbot Dafydd has been described as 'the ecclesiastical patron par excellence': ${ }^{83}$ he is the subject of, or mentioned in, as many as twenty-three poems by fourteen contemporary Welsh bards, of which eight were composed by Tudur Aled alone. ${ }^{84}$ Clearly, he was a man of influence and character as well as a capable administrator, and it was presumably these qualities that brought him into patronal contact with so many poets.

Cistercian abbots therefore could have a significant influence upon the internal organization and external relations of their respective monasteries as well as an impact on wider, secular society. While, as we have seen, the abbacy of the Welshman Thomas Pennant does not seem to have made an impression on the recruitment of new monks to

<http:/gutorglyn.net/gutorglyn/name-full/?n=na04>, accessed 02.10.202; Helen Fulton, 'The outside within: medieval Chester and north Wales as a social space', in Catherine A.M. Clarke (ed.), Mapping the Medieval City: Space, Place and Identity in Chester c. 1200-1600 (Cardiff, 2011), pp. 149-68 (pp. 158, 165).

${ }^{80}$ Davies, 'Y cerddi i'r tai crefydd', pp. 271, 279.

81 Glanmor Williams, 'Poets and pilgrims in fifteenth and sixteenth century Wales', Transactions of the Honourable Society of Cymmrodorion (1991), 69-98 (94).

82 Williams, 'Fasti' (2014), 196; David Smith has questioned whether Dafydd was abbot at Strata Florida and does not include him among the provisors of St Bernard's College: Heads, III, pp. 284-5, 319, 335-6.

83 'Abbot Dafydd ab Owain of Strata Marcella, fl. c.1480/5-d. 1513', Guto'r Glyn. net, http:/www.gutorglyn.net/gutorglyn/name/?n=na02, accessed 02.10.2020, citing A. Cynfael Lake (ed.), Gwaith Siôn ap Hywel (Aberystwyth, 1999), p. 119.

84 'Abbot Dafydd ab Owain', Guto'r Glyn.net. 
Basingwerk Abbey, it is likely that many abbots did have an effect upon the character of their conventual communities. As Martin Heale has pointed out, despite their numerous administrative and pastoral duties, late medieval heads of religious houses were often actively involved in the admission of new monks and canons: 'Abbots and priors seem to have played a central part in the recruitment of brethren to the monastery', frequently undermining the role of the convent in accepting or rejecting new candidates. ${ }^{85}$ In this case, how might the appointment of a new abbot from outside affect the recruitment process? I have discussed elsewhere the case of Hailes Abbey, Gloucestershire, where monks with distinctly northern English toponyms were admitted during the abbacies of John Crombock (1479/80-83) and Stephen Whalley, alias Sagar (1527-39), both of whom may have originated at Whalley Abbey, Lancashire. ${ }^{86}$ For Wales, we might note the comparable case of Strata Florida during the early sixteenth century. As seen above, this abbey was not only associated with Welsh cultural activities, but the names of its monks may be regarded as predominantly Welsh: in Table 4 it has the second highest percentage of linguistically or culturally Welsh forenames, after Aberconwy; and in Table 6 twice as many of the 'surnames' were either patronymics or nicknames (64 per cent) than were toponymic (29 per cent). What is perhaps significant is that the vast majority of the monks of Strata Florida who did have toponymic names are recorded in the 1510 s or later. This would coincide with the abbacy of Richard Dorstone who was originally a monk of Dore (ordained 1466x69), and was later abbot successively at Grace Dieu (1486x1488, possibly to 1495$)$, Dore (1496x1500), and finally Strata Florida. ${ }^{87}$ The exact dates of his rule at Strata Florida are not clear: he was definitely abbot around 1512 and may in fact have ruled between 1509 and $1529 .{ }^{88}$ For the period 1513-15, there are records of the ordination of four monks of Strata Florida in the episcopal registers

85 Martin Heale, The Abbots and Priors of Late Medieval and Reformation England (Oxford, 2016), p. 75.

${ }^{86}$ David E. Thornton, 'Stability or mobility? Movement between Cistercian houses in late medieval England and Wales', Citeaux: Commentarii Cistercienses, 70/1-2 (2019), 87-113 (102-4).

87 Smith, Heads, III, pp. 263, 297, 335; Williams, Welsh Cistercians, pp. 296-7; Robinson, Cistercians in Wales, pp. 241, 248, 270.

88 Smith, Heads, III, p. 335; David Williams has variously dated Dorstone's rule at Strata Florida to 1505-13 or 1509-13: 'Fasti' (2014), 197; Tudor Cistercians, p. 451; 'The Cistercians in Wales: 2. Ceredigion', 255, 271; and Welsh Cistercians, pp. 69-70, 297; Robinson, Cistercians in Wales, p. 270. 
Hereford and Worcester, and all bore toponymic bynames. ${ }^{89}$ Two of these toponyms are probably derived from English place-names, both in Herefordshire and relatively close to Dore (Howton, 4 miles; Whitney, $17 \mathrm{~m}$ ); the two others are places in Wales: Llandovery (Dovery) and Talley. Thus, during the abbacy of Richard Dorstone, himself originally a monk at Dore where the use of toponymic surnames/bynames prevailed (Table 6), we find recruits to the traditionally 'Welsh' house at Strata Florida adopting toponymic bynames, including two ordinands who were associated with places in Wales.

This example from Strata Florida is interesting because it suggests that, during Dorstone's abbacy at least, some monks at least were possibly recruited from England (close to the abbot's apparent family home), while others were recruited from within Wales but adopted toponymic bynames contrary to the prevailing practice at the abbey. Accordingly, white monks who may have identified as Welsh followed the 'English' habit of using monastic bynames under the influence of their abbot. There is evidence therefore, for the later period at least, that the adoption of monastic bynames by Cistercian monks at Welsh houses was not an indicator of ethnicity, or perceived ethnicity, but was rather the product of local conventual practice at particular abbeys. The fact that this practice was most prevalent at monasteries in the east of Wales and, in many cases, at houses less associated with Welsh culture does not in itself mean that individual monks who had a monastic toponym were necessarily from England or identified in some way as English. There is further evidence, again from the final years of Welsh monasticism in particular and derived from a handful of wills, that would support the foregoing statement. For the former male religious in England after c.1540, the wills they made as secular clerks often give the names of family members, including brothers, who bore different surnames, thus supporting the view that monks and canons had adopted a new byname on admission. ${ }^{90}$ The testamentary evidence for former Welsh Cistercians is far less extant than for England but the few examples found so far

89 Arthur Thomas Bannister (ed.), Registrum Ricardi Mayew: Episopi Herefordensis, A.D. MDIV-MDXVI, Canterbury and York Society, 27 (London, 1921), pp. 261-3, 270-1; Worcester, WRO MS b706.093-BA2648/8(i) (Reg.Gigli), fols 331, 334.

90 David E. Thornton, 'The prosopography of English monastic orders at the Dissolution: evidence from The National Archives assessed', Archives: The fournal of the British Records Association, 54 (2019), 33-58 (56-7). For examples, see Thornton, 'Locus, sanctus et virtus'. 
are suggestive. For instance, Richard Bromley, 'clerk and former prior of Valle Crucis', wrote his own will on 28 March 1566, though it was not proved until January 1577, and made bequests to his nephew called Richard ap Edwarde of Ruthin, whom he also appointed as his executor. ${ }^{91}$ Similarly, John Didbrook, subprior of Dore, is probably to be identified with the parson of Llanfair Cilgoed of the same name whose will is dated 4 February 1570 and proved a month later. ${ }^{92}$ Didbrook also made a number of bequests to various 'nephews' who are all identified using the Welsh patronymic system. In both of these examples, we find a former monk whose toponym appears to derive from an English place-name but whose relatives bore Welsh patronymic names. This would suggest that the monk, or his family at least, was 'Welsh', but that he himself had adopted a toponymic byname on admission. In these two cases, therefore, the adoption of an English-style monastic byname need not be inconsistent with the bearer himself or his family being Welsh. ${ }^{93}$

As the examples of Richard Bromley and John Didbrook would suggest, the use by a Cistercian monk at a Welsh house of an 'Englishstyle' monastic toponymic byname need not indicate that the bearer himself was English or identified as English, but rather that he had

${ }^{91}$ TNA PROB 11/59/126. For Prior Bromley, see Williams, 'Fasti' (2014), 192; Williams, Tudor Cistercians, p. 431 (the reference to Chambers, Faculty Office Register, p. 156 is incorrect); Williams, Welsh Cistercians, pp. 67-8; Smith, Heads, III, p. 345. I suspect Williams's accounts of Bromley may conflate two individuals, one called Bromfield: it seems unlikely that someone who was described as suffering from infirmity in 1528 would survive for a further 50 years.

92 TNA PROB 11/52/96. Abbey Dore had previously possessed the chapel and grange at Llanfair Cilgoed: Williams, Welsh Cistercians, p. 303. For John Didbrook, see Williams, 'Fasti' (2014), 198; and Tudor Cistercians, p. 452.

${ }^{93}$ Furthermore, in his will, dated 8 April 1548, the former abbot of Basingwerk, Nicholas Pennant, refers to himself and his brother using what we know to be their surname (not byname), but calls his beneficiaries (presumably his children) ap Nicolas Penant, and verch Nicolas Penant: Hawarden, Flintshire Record Office, MS D/NA/724; on the adoption of this surname, see Thomas Pennant, The History of the Parishes of Whiteford and Holywell (London, 1796), pp. 34-6. Other former Welsh Cistercians who left wills include William Marbury, monk of Dore and later vicar of Peterchurch, Herefs., dated 1584, and Thomas Perpyn, monk of Flaxley, subsequently abbot of Grace Dieu, and later perpetual curate at Cirencester, dated 1564: Hereford, Herefordshire Archive and Records Centre, MS 28/4/45; Sylvia Gill, 'Managing change in the English Reformation: the 1548 dissolution of the chantries and clergy of the Midland county surveys' (unpublished $\mathrm{PhD}$ thesis, University of Birmingham, 2010), 133-4, 324-6; Gloucester, Gloucestershire Archives, MS 1563/152; Smith, Heads, III, p. 298; Williams, Tudor Cistercians, p. 504. 
followed the prevailing practice at his monastery. As we have seen, at two Welsh Cistercian houses - Abbey Dore and Tintern - the percentage of toponymic names (75-78\%) approaches that of the English model, though of course Dore was technically in England anyway. The less well-documented Basingwerk lags a little behind with 66 per cent. At least in these cases, we might expect the adoption of toponyms to have worked similarly to the pattern in England: that these names were indeed toponymic byames, assumed on admission or profession, and derived from the places of birth or recent origin of their respective bearers. David Williams has certainly assumed as such, for many of his studies include a discussion of recruitment to Welsh Cistercian monasteries with accompanying maps plotting the place-names from which the locative surnames of the relevant brethren were probably derived. ${ }^{94}$ These include onomastic analyses for Dore and Tintern but also for Margam, where the percentage of toponyms versus patronymics was far below the English model. While the 'locative surnames' of the monks of Basingwerk, Dore and Tintern may well in fact have been toponymic monastic bynames, can we make the same assumption for Aberconwy or Neath, for example, where the occurrence of surnames based on placenames and/or topographical features was significantly lower?

Only a small number of the toponyms borne by Cistercian monks in Wales after 1300 were linguistically Welsh, ${ }^{95}$ and of these, the underlying place-names are mostly located in Wales, though a few had, by the late medieval period, long been in England (Ewyas, Ross). However, the vast majority of toponymic names borne by Welsh Cistercians are derived from etymologically English place-names or topographical words, located either in England - both near the Welsh border but also further afield - or in the eastern part of Wales. This is perhaps not too surprising, given that, as we have seen above, most of the toponyms are attested at a handful of monasteries in the east of Wales. Yet, the linguistic bias of the names may point to a predominantly English geographical and therefore cultural focus for their bearers. The chronological distribution

94 For example, Williams, 'Fasti' (2014), 186-7; Williams, Welsh Cistercians, p. 129; also David H. Williams, 'The Abbey of Dore', in Ron Shoesmith and Ruth E. Richardson (eds), A Definitive History of Dore Abbey (Little Logaston, 1977), pp. 15-36, 218-21.

${ }_{95}$ For example, Abergavenny, Barry, Brecon, Cam, Conway, Llandovery, Ewyas, Glyn, Gwenddwr, Heiob (Heyop), Kerry, Cedweli, Magor, Machen, Meifod, Ross, and Talley. 
of these toponymic names at individual abbeys is also significant. At certain houses (notably Aberconwy, Strata Florida and Valle Crucis) most or even all of the toponyms are attested after $c .1480$, some only at the time of the Dissolution. In contrast, at other monasteries there is a broader distribution of toponyms over time, with fewer late attestations: Cymer, Dore, Strata Marcella and Tintern. The toponyms recorded in the sixteenth century especially may not all have been monastic bynames. In England, as seen above, some Tudor monks and regular canons continued to be known by their surnames on admission and we know of a few late Welsh Cistercians who did so (Pennant and Salusbury). Furthermore, during the later 1530s when leaving their monasteries, many English religious reverted to using their surnames and appear as such in the Faculty Office Register and the pension lists. ${ }^{96}$ Finally, following the initial phase of dissolutions of smaller and attainted houses, a number of monks in England and Wales opted to transfer to other, continuing houses of the Order: for the Welsh abbeys, this included not only monks from other houses in Wales but also new brethren from suppressed houses in England. ${ }^{97}$ The latter may well have continued using their existing toponymic bynames but of course this fact would hardly inform us about the naming practices at the Welsh monasteries.

A methodology for assessing the toponyms of late medieval religious will be applied here for the names of the Welsh white monks, in an attempt to determine to what extent the Cistercians at different monasteries in Wales adopted monastic bynames. The methodology is hardly an 'exact science' and offers a general impression/pattern rather than precise numbers. The toponyms of Welsh Cistercians will be evaluated according to four criteria:

1. Was the underlying place-name derived from a settlement located relatively close to the abbey?

2. Was the underlying place-name derived from a settlement among the temporal or spiritual possessions of the abbey?

3. Was the underlying place-name derived from a settlement associated with another Cistercian house? and,

4. What is the date of attestation of individual toponyms?

96 Thornton, 'The prosopography', 45-7.

97 For some possible English transferees, note Williams, 'Fasti' (2014), 198, 209, 212; Williams, Welsh Cistercians, p. 86. 
Historians who have studied the toponymic bynames of English monks and regular canons have argued that, in general, the underlying placenames indicate a very local pattern of recruitment: most of the toponyms can be identified with places located within a 20-25 mile radius of the bearer's monastery: this is achieved by calculating the distance in miles (as the crow flies) between the underlying place and the bearer's monastery; then, adding together all distances and dividing the total by the number of bearers. In most cases, the resulting average (mean) is no more than 25 miles.

For Wales, we may start with Tintern and Abbey Dore as they are well documented and produced many toponyms. For Tintern Abbey, excluding a few 'regional' surnames (Went from Gwent, and Dorset) and those that cannot be identified, the average distance is 26 miles. This includes, at one extreme, five monks whose surname was Tintern (therefore, zero miles) and, at the other end, two whose names derive from Acle in Norfolk (217 miles from Tintern). If Acle is removed as an outlier (but see below), the average comes down to 18 miles. This would imply relatively local origins for most of the underlying place-names. In addition, we might note that a number of the underlying names appear to derive from properties of Tintern Abbey: these include the aforementioned manor at Acle, as well as other properties located closer to the abbey. For Abbey Dore the average distance is 49 miles, which seems a little high and is due to a number of toponyms derived from a cluster of closely located places in Lincolnshire and Cambridgeshire (including Wigtoft, where Dore had property, and Swineshead, which was the site of a Cistercian abbey). Other Dore properties reflected in its monks' toponyms include Albrighton, Bacton, and Gwenddwr. In addition to Swineshead, the names of a number of Dore monks may be associated with other Cistercian houses (Buildwas, Ford, Furnes/ Fontnes and Whitland) or their properties (Didbrook, above, was a manor of Hailes Abbey). Therefore, for the well-documented Dore and Tintern, where the toponyms are largely local and/or the more distant toponyms may be associated with or near property of the abbeys, it seems reasonable to assume that the brethren (mostly) used monastic bynames, like their English counterparts.

It is difficult to be quite so confident when examining the patterns for other Welsh Cistercian abbeys, especially where the number of recorded toponyms is significantly lower. On the one hand, some houses produce averages similar to those for Tintern and Dore. At Margam, where a 
number of the toponyms are recorded in the early fifteenth century, the average distance is about 25 miles. Similarly, Strata Marcella would have an average distance of 19 miles, but this increases to about 34 miles if we include Richard London (who may on the other hand have transferred from Cleeve Abbey). ${ }^{98}$ In contrast, for Abbey Cwmhir the average is about 40 miles: here we have five monks of the fourteenth century whose names are relatively local (Kerry 2, and Heyop 3) but there are also more distant toponyms, all recorded later, such as Bristol, Chester and Leicester, that increase the average. Finally, the average distance for the toponyms of some Cistercian abbeys is significantly higher than the radius of 20-25 miles. For Strata Florida, all toponyms except one (c.1487) are recorded in the sixteenth century: over half are probably derived from places in England but are not easily identifiable. At a minimal calculation, the average distance for these Strata Florida monks would be 68 miles, and at a maximal calculation, it would be as much as 93 miles! For Aberconwy - with only a handful of toponyms attested, and all late - the average distance is 79 miles, though this does include the byname of Abbot David Winchcombe (135 miles) who had been professed at Hailes Abbey originally. The average distance is also very high at Whitland ( 87 miles), where the number of toponyms is small, though there are a few dated to the fourteenth and fifteenth centuries. It is of course possible that the relatively small number of toponyms recorded for the brethren at Aberconwy, Strata Florida and Whitland abbeys may account for the high average distances for these three houses: in such cases, any outlier (place-name located far from the abbey) would have a greater numerical impact on the average than at those houses for which many more toponymic names are attested. However, it is also possible that high averages at these monasteries indicate that most or all of the relevant toponyms were in fact not monastic bynames but rather locative surnames. This analysis would suggest that the use of toponyms at some Welsh Cistercian monasteries followed the practice of monastic bynaming at English houses and may indicate the origins of their bearers. However, at other houses, it seems unlikely that toponymic names were bynames and so give no (direct) clue to the geographical home of the relevant monks.

${ }^{98}$ Williams, Tudor Cistercians, p. 487. 


\section{CONCLUSIONS}

It is not the claim of this paper that an analysis of the names of the brethren of Cistercian monasteries in Wales between 1300 and 1540 provides an exact and accurate means of determining the ethnic or cultural identities of individual monks. Indeed, the evidence presented and discussed above would suggest that the names and naming of Cistercian monks in later medieval and early Tudor Wales were by no means a straightforward matter. Taken overall, the distribution of both forenames and 'surnames' among the Welsh white monks correlated neither with the anthroponymic practices among the contemporary English monastic orders, nor with the naming patterns among the laity in Wales or those in England. The value of names as a means of determining 'ethnic identity' among the Cistercians in Wales is therefore also problematic. Analyses of names according to individual abbeys however would suggest that at certain houses the brethren predominantly bore forenames that may be regarded as 'Welsh' (linguistically or at least culturally) and were also otherwise known by means of Welsh patronymics and/or adjectival nicknames. Not surprisingly, a number of these 'onomastically Welsh' monasteries were especially associated with the promotion of Welsh historical and literary culture during the thirteenth and later centuries: notably Aberconwy, Strata Florida and Whitland. On the other hand, the fact that the brethren of certain other Cistercian abbeys in Wales bore fewer Welsh forenames and, especially, were known by means of toponyms need not ipso facto indicate that these monks had been recruited from England or the English communities in Wales. At Welsh houses such as Basingwerk, Strata Marcella and Tintern, as well as Abbey Dore in Herefordshire, it seems to have been the prevailing practice for new recruits to adopt monastic bynames, irrespective of their geographical origins or ethnic identification; but, except perhaps for Dore and Tintern, this conventual custom was not as widespread as it was at English monasteries. Furthermore, in a few notable instances, it seems likely that individual abbots could have influenced the recruitment and naming of new monks at their respective houses. Finally, it would appear that not every single toponym borne by a Welsh Cistercian monk was necessarily a monastic byname, indicating its bearer's place of birth or recent provenance, especially at those houses where Welsh personal-naming was predominant. For the Cistercian Order in late medieval and early Tudor Wales, therefore, both the typology of names 
and the apparent geographical reference of toponyms provide a useful but not entirely perfect means of determining the origins and identities of their bearers. The Cistercians lend themselves readily to such analyses, due to the relatively large number of houses of white monks in Wales and also thanks to the fruitful research of David Williams. It would be interesting to determine whether prosopographical studies of the other monastic orders in Wales would reveal similar anthroponymic patterns, and also what the names of the Benedictines and the Augustinian and Premonastratensian canons in late medieval Wales may reveal about the identities of these other religious houses. 